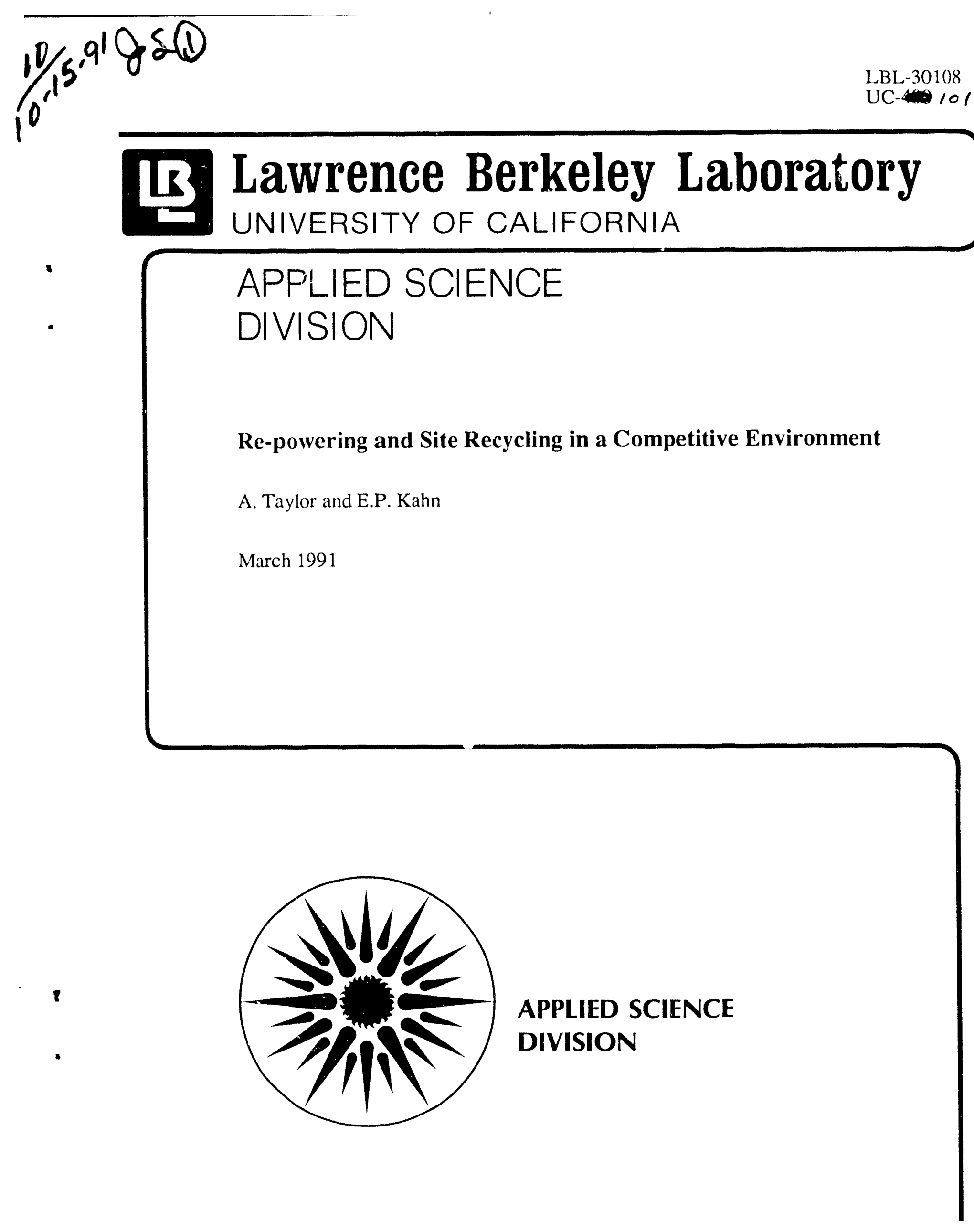




\section{DISCLAIMER}

This document was prepared as an account of work sponsored by the United States Government. Neither the United States Government nor any agency thereof, nor The Regents of the University of California, nor any of their employees, makes any warranty, express or implied, or assumes any legal liability or responsibility for the accuracy, completeness, or usefulness of any information, apparatus, product, or process disclosed, or represents that its use would not infringe privately owned rights. Reference herein to any specific commercial product, process, or service by its trade name, trademark, manufacturer, or otherwise, does not necessarily constitute or imply its endorsement, recommendation, or favoring by the United States Government or any agency thereof, or The Regents of the University of California. The views and opinions of authors expressed herein do not necessarily state or reflect those of the United States Government or any agency thercof or The Regents of the University of California and shall not be used for advertising or product endorsement purposes.

This report has been reproduced directly from the best available copy.

Available to DOE and DOE Contractors from the Office of Scientific and Technical Information I'.O. Box 62, Oak Ridge, TN 37831

Prices available from (615) 576-8401, FTS 626-8401

Available to the public from the

National Technical Information Service

U.S. Depariment of Commerce

5285 ['ort Roy'al Road, Springficld, VA 22161

Lawrence Berkeley Laboratory is an equal opportunity employer. 
LBL- -30108

DE92 000726

\title{
Re-powering and Site Recycling in a Competitive Environment
}

\author{
Alan Taylor \\ Edward P. Kahn \\ Applied Science Division \\ Lawrence Berkeley Laboratory \\ University of California \\ Berkeley, CA 94720
}

March 1991

The work described in this study was funded by the Deputy Assistant Secretary for Coal Technology under Contract No. DE-AC03-76SF00098. 


\section{Table of Contents}

Abstract $\ldots \ldots \ldots \ldots \ldots \ldots \ldots \ldots \ldots \ldots \ldots \ldots \ldots \ldots \ldots$ iii

1. Introduction $\ldots \ldots \ldots \ldots \ldots \ldots \ldots \ldots \ldots \ldots \ldots \ldots \ldots \ldots$

2. Analysis of the Re-powering and Site Recycling Alternatives $\ldots \ldots \ldots \ldots$

2.1 Utility Re-powering or Life Extension-Ratebase Regulation . . . . . . 4

2.2 Utility Re-powering or Life Extension with Regulatory Pre-Approval .......................... 5

2.3 Utility Re-powering or Life Extension and Competitive Bidding . . . . 5

2.4 Utility Leasing for IPP Re-powering $\ldots \ldots \ldots \ldots \ldots \ldots$

2.5 Utility Selling the Site for IPP Re-powering $\ldots \ldots \ldots \ldots \ldots$

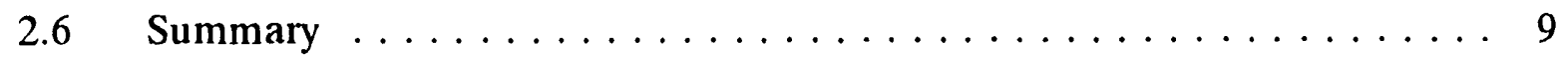

3. State Regulatory Policy $\ldots \ldots \ldots \ldots \ldots \ldots \ldots \ldots \ldots$

$3.1 \quad$ Explicit Profit Sharing $\ldots \ldots \ldots \ldots \ldots \ldots \ldots \ldots \ldots \ldots$

3.2 Implicit Profit-Sharing $\ldots \ldots \ldots \ldots \ldots \ldots \ldots \ldots \ldots \ldots \ldots \ldots \ldots \ldots \ldots$

3.3 Mixing Competition with Regulation $\ldots \ldots \ldots \ldots \ldots$

4. Conclusions $\ldots \ldots \ldots \ldots \ldots \ldots \ldots \ldots \ldots \ldots \ldots \ldots \ldots \ldots$

5. Acknowledgements .......................... 14

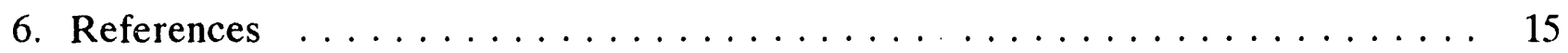




\section{-}




\begin{abstract}
Re-powering and site recycling are strategies designed to expand electric generating capacity by using existing depreciated assets. The resource base for these strategies is large. By 1995 , over 170,000 MW of fossil-fired capacity will be in excess of thirty years old, and approaching the end of its conventional economic lifetime. This paper explores how these assets might be developed using competitive market forces. While some re-powering is being pursued under traditional ratebase regulation, there are four other generic alternatives. These are: (1) utility investment at fixed prices with regulatory pre-approval, (2) utility investment under competitive bidding, (3) utility leasing for private producer development, and (4) utility sale of sites for private producer development. Issues associated with each alternative are explicied and illustrated with examples.

State regulatory policy will be the critical determinant of whether a market develops for depreciated power plants. Financial incentives will stimulate utilities to re-deploy depreciated assets. This means some form of profit-sharing between customers and shareholders of the gains from asset sales. Different approaches to profit sharing are reviewed. These developments are still in an experimental state, however, and no single approach appears to have emerged as a dominant trend.
\end{abstract}




\section{Introduction}

The coming decade may see another potential shortage of electric generating capacity. New yower plant construction declined considerably in the 1980 s from the levels it had reached in previous decades. The adverse outcomes of utility construction of the 1970s has produced deep changes in the institutional structure of the electric utility industry. Planning and forecasting have become much less predictable. Political conflicts between the state regulators and the investor-owned utilities have created an atmosphere of mutual distrust that is hostile to future investment along traditional lines.

The rapid aging of the existing stock of power plants will also increase the need for new generation resources. Statistics on the age distribution of plants show that by 1995 more than $170,000 \mathrm{MW}$ of capacity will be in excess of thirty years old. Typically, power plants have a useful life of thirty to forty years (EPRI, 1986). The regional breakdown is shown in Table 1 (USOTA, 1989).

The emergence of a private, unregulated power generation industry is one development of the 1980s which may improve the power supply situation in the 1990s. Initially developed as Qualifying Facilities (QFs) under the rules implementing the Public Utilities Regulatory Policy Act (PURPA), this segment has expanded recently to another class of private suppliers called Independent Power Producers (IPPs). QFs were predominantly based on cogeneration applications. IPPs, an as yet more limited phenomenon, generally build larger conventional facilities.

The unregulated power generation market has become increasingly organized into a system of competitive bidding solicitations in which regulated utilities solicit bids from private suppliers for a specified amount of capacity. Competitive bidding has become widespread (Wellford and Robertson, 1990). While many aspects of this process are still evolving, two issues have emerged to date that strongly affect the future supply prospects for electricity. First, private producers often have more trouble over site-related issues than any orher aspect of development. Second, even in jurisdictions that have placed principal reliance on private power development to meet future need, it is not clear whether this segment alone can meet future requirements.

This paper will examine the set of issues raised simultaneously by the prospects of large-scale future retirement of existing old power plants, the emergence of competition in the generation market, and the need for significant amounts of new generating capacity. We consider explicitly the alternative ways in which existing power plant assets can be used to meet future requirements. The residual value of old power plant sites turns out, upon examination, to be considerable. This is most easily demonstrated by examining the treatment of site-related issues in the competitive bidding solicitations recently sponsored 
Table 1: Fossil-Fired Steam Plants 30 Years or Older in 1995

\begin{tabular}{||l|c|c|c||}
\hline \multicolumn{1}{|c|}{ Region } & MW & $\begin{array}{c}\text { Percentage of } \\
\text { Fossil-Fired } \\
\text { Capacity }\end{array}$ & $\begin{array}{c}\text { Percentage of } \\
\text { Installed } \\
\text { Capacity }\end{array}$ \\
\hline \hline ECAR & 33,335 & 32.9 & 31.9 \\
\hline ERCOT & 12,186 & 20.4 & 22.0 \\
\hline MAAC & 11,589 & 35.5 & 22.0 \\
\hline MAIN & 14,172 & 41.3 & 28.0 \\
\hline MAPP (U.S.) & 6,695 & 25.8 & 22.5 \\
\hline NPCC (U.S.) & 16,806 & 52.6 & 30.0 \\
\hline SERC & 32,239 & 35.8 & 20.9 \\
\hline SPP & 21,359 & 30.0 & 32.0 \\
\hline WSCC & 24,811 & 39.5 & 18.5 \\
\hline \hline Total & 173,192 & 34.0 & 24.6 \\
\hline
\end{tabular}

Source:

U.S. Congress Office of Technology Assessment, "Electric Power Wheeling and Dealing: Technological Considerations for Increasing Competition," OTA-E409, Washington, DC, U.S. Governn. ...t Printing Office, May 1989, p. 163.

by utilities with a proximate need for new resources. Proposals that are favorably sited in the transmission network derive competitive benefit (Florida Power and Light, 1989b, 1990; Shirmohammadi and Thomas, 1990). Other site related advantages include access to fuel supply infra-structure, access to cooling water, and environmental permits. Existing power plants, even at the end of their traditional lifetimes, commonly have all these assets.

At the end of their normal operating lifetime, there are three options for old generating units that have been analyzed to date: the plant can be closed, it can be upgraded by life extension investments, or it can be re-powered. The distinction between life extension and re-powering essentially involves the difference between shorter time horizon/low capital cost actions and long time horizon/high capital cost actions. Life extension involves relatively minor equipment replacements designed to last at most twenty years. Re-powering usually includes boiler replacement or the addition of gas turbines that will last thirty years or more. Re-powering has the additional distinction that the capital 
equipment added will typically meet strict environmental regulations. One important reason why the re-powering option will be "cleaner" is that such projects commonly increase capacity at the site substantially (USDOE, 1987), and therefore must meet New Source Performance Standards.

We add one new term to the discussion of options which emphasizes the residual value of old power plant sites. We distinguish cases that we call "site recycling." These cases are distinct for one of two reasons. Either the utility uses the site for a new power plant without relying on any of the existing power generating equipment, or it transfers control of the site to a private party who independently develops a power project, which may be re-powering or an entirely new plant.

The cases involving transfer of site control to independent parties are important for a variety of reasons. First, the magnitude of the retiring plant resource base is so large that it is unlikely to be fully exploitable by the regulated utilities. Secondly, these utilities show reluctance to invest under traditional rate base regulation. The existence of a competitive private generation segment could have a beneficial effect on the development of the repowering market.

The plan of this paper is to review the alternative arrangements for site-recycling and re-powering in section 2 . This material is very case-specific, because individual circumstances vary widely. Throughout this discussion the role of federal environmental regulation and state economic regulation will be pervasive. The analysis in section 2 raises issues about the incentives in state economic regulatory policy for efficient site recycling. section 3 examines these questions in more detail by reviewing analogous situations. Section 4 offers some conclusions.

\section{Analysis of the Re-powering and Site Recycling Alternatives}

We survey below the different arrangements under which re-powering and site recycling are being carried out and analyze the regulatory and business arrangements that are conducive to sensible and efficient use of potential re-powering resources.

A review of recent develcpments in the re-powering market has revealed five possible courses of action that projects tend to take. This list includes in various ways the effects of competition in the power markets. The advent of competitive forces in a traditionally regulated market can be socially productive because competition provides for a greater variety of ways that resources can be utilized and at lower cost. With these developments in mind, we investigate what arrangements are taking place and analyze alternatives to achieve the best benefits of competition. Current re-powering arrangements can be classified as: 
1. the utility extends the life or re-powers the plant itself, seeking standard rate-ofreturn regulatory treatment,

2. the utility pre-approves a plan with the state commission to extend the life or repower the plant itself, submitting a binding cost estimate,

3. the utility puts forward its own life extension or re-powering plan which then vies with outside resource proposals in a competitive bidding process,

4. the utility leases the site to a developer for re-powering, or,

5. the utility sells the site to a developer for re-powering.

\subsection{Utility Re-powering or Life Extension-Ratebase Regulation}

The first scenario is the traditional process. The utility invests capital to extend the life of existing units, or to re-power them. Costs are capitalized and recovered in rates through additions to ratebase. There are a number of examples of this process. Florida Power and Light is proposing to re-power its Lauderdale 4 and 5 units. Existing steam turbines and generators will be augmented by new combustion turbines and heat recovery equipment. The capacity of each unit will increase from $137 \mathrm{MW}$ to $365 \mathrm{MW}$ and the fuel efficiency will improve by at least $25 \%$ to approximately $8000 \mathrm{Btu} / \mathrm{kWh}$ (Florida Power and Light, 1989a).

Another example is the proposed re-activation of the Duquesne Light Company (DLC) Phillips Station (300 MW coal-fired) and Brunot Island Combined Cycle Station (267 MW gas-fired). In this case, DLC placed the units on cold reserve status due to declines in demand. Their re-activation is connected to a proposed long-term sale of capacity to General Public Utilities (GPU). The DLC-GPU sale is a complex transaction involving new transmission facilities and innovative regulatory proposals (Duquesne Light Company, 1990). To complete the transaction, the Phillips Station, in particular, will require considerable retrofit investment to sustain high availability over the twenty year term of the agreement (Jones, 1990). Regulatory issues associated with the DLC proposal are discussed in section 3 below.

Some of the issues associated with utility life extension or re-powering projects revolve around the ambiguities associated with the definition of regular on-going maintenance and improvements. For instance, in 1988, the Wisconsin Electric Power Company (WEPCO) proposed extending the lifetime of its 400-MW Port Washington plant with $\$ 80$ million of capital improvements. The Environmental Protection Agency (EPA) found the improvements to be "non-routine" and therefore subject to PSD (prevention of significant deterioration) and NSPS (new source performance standards) review. This meant 
that under these circumstances, the plant potentially had to meet NSPS for several of its units. To achieve this, WEPCO would have to put scrubbers on the old plant, thereby increasing the cost of the project very substantially. After adjudication, the U.S. Court of Appeals (1990) upheld EPA's requirement that PSD applies in this case. The cost of compliance increased to $\$ 120$ million, and WEPCO decided to retire one of the $80 \mathrm{MW}$ units (Steinberg, 1991; Power and Energy Briefs, 1990). This raised the cost to $\$ 375 / \mathrm{kW}$ from the original estimate of $\$ 200 / \mathrm{kW}$.

The uncertainties surrounding the outcome of this case (and its ramifications for otkei projects around the country) cast a pall over the future attractiveness of life extension. This could push more projects over the line into the re-powering or site recycling alternatives by making life extension relatively more expensive.

\subsection{Utility Re-powering or Life Extension with Regulatory Pre-Approval}

This case differs primarily from the traditional option in the nature of the state regulatory treatment of costs. Instead of a system under which utilities make capital expenditures and subsequently seek cost recovery in rates, pre-approval eliminates potential after-the-fact prudency review. Traditional ratemaking provides the opportunity to disallow expenditures deemed imprudent by the regulator. The pre-approval alternative not only deems the project useful, but fixes the level of cost recovery in advance of actual expenditures. To date only one state, Massachusetts, has chosen this approach.

In October, 1988, the Massachusetts Department of Public Utilities (MDPU) mandated that any utility intending to make incremental capital investments in a plant in excess of $\$ 250 / \mathrm{kW}$ had to submit the plan to the MDPU for pre-approval (MDPU, 1988). The cost estimate would be binding and would serve as a budgetary incentive target. This approach is a cost cap which limits ratepayer exposure to cost over-runs, and provides the utility with an opportunity to earn extra profit from efficient management. If the actual utility costs were to exceed the estimate, its shareholders would have to bear the burden of the additional costs; if the utility were to come in under budget, its shareholders would retain the additional revenues as profits.

The MDPU rules require that any life extension or capacity expansion of a generation facility, i.e. re-powering, be subject to the pre-approval process, even if the cost is less than $\$ 250 / \mathrm{kW}$. As of February, 1991, no utilities have approached the MDPU for this pre-approval process except for demand-side proposals (Wolfe, 1990; Litkovitz, 1991). 


\subsection{Utility Re-powering or Life Extension and Competitive Bidding}

Some utilities have included their own proposals for re-powering or life extension in a competitive bidding process. Competitive bidding is a recent utility practice that involves a public request for future generating capacity (to be built and operated by independent developers), followed by an evaluation and selection process among the proposals received. Two New York utilities, Niagara Mohawk Power Corporation and Consolidated Edison, have proposed that their own life extension projects compete with the developers' proposals.

Some regulators question whether a utility can make objective decisions among competing proposals when one of those proposals is its own. Considering that the developers are bound to their price by a purchase power contract, some have insisted that the utilities must also be bound to their re-powering or life extension cost estimate, should they end up choosing their own project. We examine in detail one of these cases.

Niagara Mohawk Power Corporation (NMPC) has proposed two life extension projects for old coal plants as bids in its 1989 competitive bidding solicitation (NMPC, 1989a). These projects are not designed to improve the emissions performance of the units involved, but simply to extend their useful lives. The two projects are somewhat different. Huntley 64 is an $85 \mathrm{MW}$ unit which is planned to continue in service until 2009. Huntley 67 is a $185 \mathrm{MW}$ unit whose service life would be extended to 2017.

While NMPC has not published cost data for these two projects, it is reasonable to assume that the cost is low. Somewhat analogous cases, where cost data have been published, involve old coal plants owned by Public Service Company of Indiana (PSI). In these cases, PSI estimated twenty year life extension costs in the $\$ 160-270 / \mathrm{kW}$ range (Benning, 1989). An EPRI study of life-extension investments developed estimates averaging $\$ 282 / \mathrm{kW}(1983 \$$ ) for a large-scale multi-unit program where service life would be extended twenty years (Farber, 1985).

The uncertainty over implementation of new Clean Air Act requirements raises a number of complex bid evaluation issues for these projects. The basic question involves the need for scrubbers. Most discussion of Clean Air Act requirements focuses on implementation of expensive controls such as scrubbers which will be required by January 1, 2000 . Representative costs for scrubbers are in the range of $\$ 200-250 / \mathrm{kW}$ (1989 \$). What is uncertain is the need for scrubbers on any particular unit. If Huntley 64 and 67 were not required to have scrubbers, their costs would probably be very difficult to beat with a greenfield, i.e., new construction, project. If, on the other hand, they were required to have scrubber retrofits, the competitive position of these projects is considerably diminished. This effect is more dramatic for Huntley 64, since its remaining life after 1999 is only 10 years, compared to 18 years for Huntley 67. 
The cost uncertainty is particularly difficult to accommodate in the framework of competitive bidding. The nature of decision-making in this setting does not easily accommodate contingent costs. NMPC is using a unique approach to bid evaluation that may help to address this problem. Bids will be evaluated in two stages. Stage 1 is essentialiy a screening exercise to determine a short list of bidders whose projects will be examined in more detail. The screening is done by using a self-scoring bid evaluation procedure that will be performed by an independent third party. The third party's responsibilities include verifrying the dara submitted by bidders and certifying that bids meet the threshold requirements of the solicitation. Once the short list has been selected by the first stage process, NMPC itself will evaluate bids to determine the best mix of offers to meet its need requirements.

This procedure has the potential to resolve the ambiguities associated with the NMPC life extension proposals. The third party evaluator will determine if the life exi-nsion bids meet the threshold requirements of the RFP. Private competitors, participating in NMPC's Pre-Bid Public Meeting, expressed concern that there was an asymmetry in the process. In particular, greenfield projects would have to meet NSPS requirements as a threshold, whereas the NMPC life extension bids would not. The company's response to these questions was that these were issues for the third party, and that NMPC would not disclose details of their bid (NMPC, 1989b).

It remains to be seen what the outcome of this case will be. The third party evaluator may legitimize the bid without scrubbers or require them. If there is no requirement, and the projects are accepted, there will be a cost allocation issue in the event that scrubbers are eventually required for these units. Presumably, the costs of scrubbers should not be borne by ratepayers in such a case. If, however, ratepayers do not bear these costs, then there is a considerable likelihood that the projects would cease to operate. Premature termination of these projects would call into question the value of selecting them in the first place.

Questions such as these illustrate the kinds of problems that arise when regulated and competitive activities occur within the same firm. The potential for self-dealing in these situations cannot be ignored. The ability of regulation to anticipate cases where self-dealing may occur is limited. Once such abuses are detected, there is much less difficulty correcting them. In this particular example, the ambiguities surrounding Clean Air Act implementation will be resolved. The generic lesson, however, is that some other cost ambiguity of a similar kind can occur in the future. If utility life extension or re-powering projects are to compete with private projects, seif-dealing uncertainties may stili persist. These uncertainties can have negative effects both on re-powering/life-extension projects and on the competitive bidding process. 


\subsection{Utility Leasing for IPP Re-powering}

Some utilities have opted to shift the risk of re-powering cost overruns onto independent power producers (IPPs) by leasing the site to the developer. The IPPs are bound by their bid price. By not doing the re-powering itself, the utility is insulated from potentially onerous regulatory treatment because purchase power contracts are signed and approved by the regulators before the re-powering project begins. This leasing alternative also keeps the land in the utility's hands should it want to develop other resources there at the end of the re-powered facility's lifetime.

From the IPP's standpoint, leasing a site does not afford as much flexibility and control as actually purchasing the site; but the IPP may get a better price or a more attractive financing arranyement with the leasing option. Under this situation, the IPP is exposed to various risks that may derail the project.

For example, one such case involved a developer who negotiated with a utility to lease the site of a small, old, coal-fired plant for the purpose of building a fluidized-bed coal-combustion facility. Without actually having title to the land, the developer found his options were limited when plans began to change. First, the lease stipulated that the site could not be used to generate power for sale to anyone other than the lessor-utility, thereby precluding any wheeling possibilities. Second, when the deal was subsequently stymied by disagreements over purchase power price, it left the developer (who had invested a great deal of effort and money in the project's permitting process) with far fewer potential buyers for the project than if he had originally procured the actual title to the site.

A more successful outcome is represented by the Mission Energy/Sunrise project in Nevada. Nevada Power Company (NPC) has experienced substantial load growth in recent years. This has stimulated a major capacity expansion program that includes both new generation and increased transmission linkages. Despite these efforts, NPC decided in 1989 that it would have a capacity deficit by 1991 unless it could acquire $200 \mathrm{MW}$ of peaking capacity by that time. After reviewing its alternatives, NPC chose to contract with Mission Energy Company for $210 \mathrm{MW}$ of combustion turbines to be constructed at its own Sunrise power station near the Las Vegas load center. NPC would lease part of the site to Mission, who would build the project and be paid under a long term purchase contract. NPC would supply the gas to fuel the facility, and actually operate it.

NPC submitted the contract with Mission for this arrangement to the Public Service Commission (PSC) in March, 1990. The PSC held six days of hearings on the proposed arrangement, which proved to be controversial. In its Opinion and Interim Order, the PSC rejected the contract, principally because its cost was deemed excessive, and ordered NPC to pursue alternatives to the proposed arrangement (NPSC, 1990a). The two principal alternatives suggested by the PSC were renegotiation of the price with Mission, or purchase of Mission's interest by NPC. Renegotiation of price was subsequently agreed upon by the 
parties. The revised contract was submitted to the PSC, and accepted on the basis that the revised costs were now similar to those that would have been incurred if NPC itself had built the project (NPSC, 1990b).

The Mission/Sunrise case raises a number of important issues. First, the motivation of NPC for choosing this option was explained in the public hearing. NPC felt constrained by the urgent need for new capacity that was not anticipated by previous forecasts. The time horizon for choosing alternatives was very short. NPC had experience with QF suppliers, but felt that standard baseload QF projects were inappropriate for what was basically a peaking requirement. The utility chose Mission as a supplier because they had previous experience with the firm as a QF developer. Further, NPC felt that Mission's financial ties with the Southern California Edison Company made it financially strong. NPC's other construction commitments were so large, that the utility felt its credit rating would be harmed by constructing the project itself. Finally, transmission and siting constraints made the NPC Sunrise site an ideal location for the project.

Lack of competition for the opportunity to construct this project was raised as an issue during the hearing. The Opinion and Interim Order did not address that concern explicitly. The principal concern of the PSC was the price, which was deemed excessive. While an explicit competitive process may well have resulted in a lower price, it is not clear that this could have been achieved under the time constraints facing NPC. Further, NPC expressed discomfort at the prospect of working with a firm that it had not dealt with previously. Even in a more competitive scenario, it is not clear that the Sunrise site would have been available to all bidders.

\subsection{Utility Selling the Site for IPP Re-powering}

A recent survey of the industry has turned up several instances where utilities have sold existing power production facilities and/or sites - assets which have ultimately ended up (intentionally or unintentionally) in the hands of independent power producers for repowering. None of the cases to date seem to represent the execution of a well thought-out resource plan. Either the IPP had acquired the site by accident, or the utility had been in a state of financial distress and had desperately needed cash.

An example of the first kind of scenario involves Consumer Power's Morro power station in Kalamazoo, Michigan. A 186 MW plant, the Morro facility was built in 1939 and originally fired with coal, converted to oil, then to gas, and back to coal; it was retired in 1983. When the plant was first built, the Kalamazoo River had been dammed to provide a cold reservoir for waste heat disposal. In 1984, STS Inc. (based in Chicago) bought the entire Morro property to utilize this lake for a small hydro project, less than $1 \mathrm{MW}$. Consumers' Power was under extreme financial pressure resulting from their derailed Midland nuclear power project. Seeking cash to abate their financial crisis, the utility sold 
the site, presumably never expecting the retired Morro thermal plant to be re-powered. Several years later, Nordic Power (an independent private developer based in Ann Arbor, Michigan) bought the plant from STS to re-power it as a combined-cycle operation (Strait, 1990).

Another instance where financial distress is playing a role in a utility's motivation to sell a plant is occurring in North Dakota. Basin Electric Cooperative recently offered to sell the William J. Neal powerplant (a $50 \mathrm{MW}$ lignite unit) to Ethacoal North Dakota Corporation. Basin had a substantial amount of excess capacity. Ethacoal would like to purchase the Neal plant to re-power it as a cogeneration facility producing ethanol and animal feed as byproducts and selling the electricity to Northern States Power, but no deals have been struck to date (Keller, 1990).

A successful transaction occurred in 1983 when Gulf States Utilities sold an unused site to CITGO for development as a QF. The motivation on the utility side was financial distress, as in the two other instances cited above. These examples illustrate the general lack of an ordinary business motivation to re-deploy under-utilized utility assets.

Many private developers have been frustrated in their attempts to enter the repowering market through the purchase of an existing power plant/site. Some developers have offered in the neighborhood of $\$ 500 / \mathrm{kW}$ for small-scale retired power plants, only to have utilities demand three times that much for the sale (Naill, 1990). This stalemate has prompted some to conclude that the only way they can obtain an existing power site from small utilities may be to execute a takeover.

\subsection{Summary}

This survey has not conveyed any dominant trend. There are examples of most approaches to re-powering and site recycling, but no clearly preferred option. While it is clear that some re-powering will occur under ratebase regulation, it is unlikely that this approach alone will realize the potential asset value. The analysis of alternative approaches reveals that they will be strongly influenced by regulatory policy. Currently, regulators do not give active attention to those options which involve transfer of control over these sites and projects to private suppliers. The utilities, with a few exceptions, have not actively promoted this option. Therefore we have a competitive sector of the wholesale power market that may be willing buyers of depreciated utility assets, but we do not have willing sellers.

This predicament is understandable when one examines the incentives and motivations on the part of utilities (those that are investor-owned, in particular) for selling off retired power plants. In the case of a utility that is suffering financially, the need to raise cash may prompt the company to sell off a site that is no longer being used. But in 
the case of a financially healthy utility, the incentives behind such a transaction are principally determined by the state and federal regulators. Specifically, a utility has no incentive to sell off a retired plant unless it can capture some portion of the proceeds as profits for its stockholders. Therefore, the extent to which the re-powering market will be open to IPPs will depend in large measure on the policies that regulators implement regarding the disposal of old assets.

In the next section we review state regulation related to gains from assets disposition. This regulatory record will illustrate the kind of issues and outcomes that would arise in a more explicit policy toward the re-powering and site recycling resource option.

\section{State Regulatory Policy}

Over a dozen state commissions have passed rulings during the past decade determining whether a utility's ratepayers or stockholders should get the proceeds from the disposition of various utility assets. There has been no general agreement over who sho'id get the profits (or how those profits should be split). Invariably, most commissions have examined this issue on a case-by-case basis, often declaring that the outcome of a case does not necessarily have any bearing on future decisions. For the most part, the relevant regulatory rulings have dealt with selling land that was purchased for power plants that were never constructed, selling off a partial ownership in a unit, and disposing of old administrative buildings and small pieces of distribution systems.

In this section we review regulatory decisions that broadly address issues related to asset disposition and the sharing of benefits from market activity outside of franchised monopoly service. State regulation can create incentives for efficient behavior or inhibit them. The role of incentives in electric and gas utility regulation is being studied with increasing sophistication (Joskow and Schmalensee, 1986; Brown, Einhorn and Vogelsang, 1989). The role of incentives involving asset sales has not been examined closely.

We divide the discussion into two parts, which we call explicit profit-sharing and implicit profit-sharing. In the former case, regulators make a clear decision or set a precise formula under which transaction benefits are distributed. The latter case involves sharing arrangements that are either too complex or indeterminate to associate with precise sharing formulas. We will find more examples related to re-powering and site recycling in the latter category than the former. 


\subsection{Explicit Profit Sharing}

These cases involve asset sales or bulk power transactions where the regulatory record yields a clear allocation. The transactions all have a fairly standard quality to them, which perhaps makes explicit rules easier to formulate than when the transaction is unique.

The most common type of electric utility asset sale case involves the disposition of excess real property. A representative example of a land sale ruling is the case involving Rochester Gas and Electric's (RG\&E) loss of \$7.4 million when the utility sold to its unregulated subsidiary the land it had accumulated for the Sterling nuclear power plant. Sterling was a planned project which was ultimately cancelled. In 1985, the New York Public Service Commission allowed RG\&E to recoup its loss from its ratepayers but mandated that $80 \%$ of any gains from reselling the land in the near future had to be shared with the ratepayers (NYPSC, 1985).

In another cas: ', Pacific Gas and Electric bought some coal properties in Utah for the purpose of building a power plant. When the construction plans were cancelled, the land was sold at a gain. Most of the net proceeds from the sale were flowed through to the ratepayers, although some of the gains were retained by shareholders (CPUC, 1982).

Other regulatory rulings have examined the issue of allowing utilities to capture additional profits for their stockholders (above the traditional "fair return") by surpassing predefined performance targets. For example, the New York Public Service Commission has established incentive regulatory agreements with most member utilities of the New York Power Pool concerning fuel costs and economy sales. In both cases, monthly targets are set by the Commission. If the utility can operate its system efficiently enough and come in under buiget on fuel costs, utility stockholders get to keep $20 \%$ of the first $\$ 10$ million in savings and $10 \%$ of the next $\$ 10$ million. Likewise, the stockholders symmetrically share in the "loss" if fuel costs exceed the target level. A similar 80\%/20\% ratepayer-stockholder split has been arranged to promote economy sales transactions (NYPSC, 1983).

Commonwealth Edison also has a fuel budget incentive ratemaking program with its regulatory commission. The Illinois Commerce Commission (ICC) has established a $50 \% / 50 \%$ split between ratepayers and stockholders on any gains or losses on the budgeted fuel costs. Specifically on the issue of asset dispositions, the ICC has come to opposite conclusions on a variety of cases, sometimes giving stockholders the profits from asset sales, and other times flowing the gains through to the ratepayers. Factors affecting the decision include whether the asset was ever in the rate base, for how long, and whether it appreciated or depreciated relative to the original investment. Currently the ICC is working to establish a clear, well-defined policy for the regulatory treatment of asset dispositions (Hoppe, 1990). 


\subsection{Implicit Profit-Sharing}

The transactions described here are substantially less routine than those described above. They all involve the re-deployment of assets that are deemed "excess" in one way or another. In each case the particular situation raises unique issues of regulatory policy. The complex circumstances are not amenable to explicit formulas for the allocation of benefits.

Questions of regulatory jurisdiction and the pricing of transferred assets have recently arisen in Arkansas. Arkansas Power and Light (AP\&L) has moved to transfer its ownership interest in two generating units to Entergy Power Inc. (EPI); both AP\&L and EPI are subsidiaries of the same holding company, Entergy Corporation. The Arkansas Public Service Commission approved the sale in April 1990 since AP\&L had excess capacity and the transaction would relieve the utility's ratepayers of the costs of unused capacity, i.e., reduce the rate base. The commission's order allowed AP\&L to sell the assets at book value. The Arkansas Electric Energy Consumers (AEEC), a group of industrial customers, complained that book value price is too low; AEEC and other groups will no doubt contest the pricing of this transaction in AP\&L's next rate case (Bruce, 1990).

Another complication to the transaction involves complaints from sister utility subsidiaries in the Entergy Corporation power pool. Apparently, EPI will sell the power off of the system; so affiliated utilities like New Orleans Public Service are concerned that the costs to their ratepayers will go up (since these inexpensive resources will no longer be in the pool's economic dispatch and demand will be met with higher-priced generation). FERC is being urged to review the transaction (Bruce, 1990).

In a second example, Public Service of Indiana (PSI) has made a proposal to state and federal regulators concerning some of the older generating facilities on the utility's system. Although PSI is not interested in physically selling these assets per se, it is interested in having the generation from these mostly-depreciated coal plants compete in an open market. In return for granting "open access" to its transmission system (and thereby guaranteeing that it cannot exercise market power over potential power purchasers), PSI wants to be allowed to line up $450 \mathrm{MW}$ of firm sales at rates that are competitive with the purchasers' avoided costs (Rodgers, 1990).

Traditionally, rates would depend on the book value of the units generating the power. However, these units are almost fully depreciated, and hence conventional regulation would price their power very cheaply. With this new arrangement, though, PSI will negotiate contracts at market rates that are considerably higher than the traditionallycalculated rates. The profits made from this new approach will be shared between ratepayers and stockholders, allowing PSI to reduce its revenue requirements and rebuild its weakened equity position (which was substantially impaired by the $\$ 2.7$ billion Marble Hill write-off). 
The third example of this kind involves the re-activation of power plants in cold reserve proposed by Duquesne Light as part of its long term capacity sale to GPU. This transaction was described briefly in section 2.1 above. Here we emphasize the proposed regulatory treatment. DLC seeks ratemaking treatment for the transaction which would benefit both shareholders and customers. The customer benefit would come in the form of revenue reductions based on the proceeds of the sale. These revenues are expected to be greater than the costs DLC would incur. Customer rates would be reduced by the excess of revenues over costs.

There are two elements of the transaction that would benefit shareholders. First, DLC proposes to include in the costs those expenses it incurred to preserve the units while in cold reserve. These preservation costs were not billed to customers, but were absorbed by shareholders (Clayton, 1990). Recovering them amounts to implicit profit-sharing. Secondly, DLC proposes that rate adjustments for the transaction be deferred until it is necessary for the company to file for a general rate case. In the interim period DLC would retain for shareholders the revenues from the sales to GPU.

The Pennsylvania Public Utility Commission has yet to rule on these proposals. There are other elements of the transaction that also require authorization.

\subsection{Mixing Competition with Regulation}

These examples indicate a trend away from the conventional regulation and toward more competitive market orientation. It remains to be seen if this orientation will be adopted by other utilities that also have old generating facilities. Once an old power plant is fully depreciated, the utility has recaptured its original investment, and there is no way to extract any more revenues from the asset. Since the plant/site still has a substantial intrinsic market value, the utility may want to tap some of that value by selling off the facility in an arm's length transaction (e.g., to an IPP for re-powering). Such a transaction would require some sort of incentive profit-sharing regulatory policy to be in place so that the utility could be sure that its stockholders would benefit. In the absence of profitsharing, the utility has no incentive to utilize assets with considerable social value.

There is no clear indication whether state regulation will be congenial in the long run to market-oriented mechanisms that will increase utilization of old power plants and their sites. It is always difficult to mix market methods with traditional cost-of-service regulation. Such a mixture requires guidelines defining the boundaries between regulated and competitive activity. These boundaries are frequently shifting and involve spill-over effects. The problems of potentially abusive self-dealing, noted in section 2.3 above are one illustration. It is inevitable, however, that experimentation will proceed. The tasks are complicated because road maps are constantly being re-drawn. 
For example, the asset and site transfer alternatives interact with new forms of environmental regulation. Both the leasing and the sale alternatives raise questions associated with Clean Air Act modifications. The system of emission reduction credits (ERCs) was created under the anticipation that ERCs will be actively traded in a pollution control market, leading to an economically efficient approach to control costs. There are many questions surrounding this concept and its implementation. Of particular concern are questions concerning the ability of independent power producers to participate equitably in the ERC market (Hausker, 1990). Site recycling options raise several issues associated with ERCs. Do the ERCs get transferred with the plant? Who resolves ERC disputes that might arise out of site recycling? Will uncertainties about ERC treatment inhibit site recycling? At the current state of discussion, no clear answers are possible. The creation of an ERC market might encourage site-recycling by sensitizing utilities and state regulators to the issue of profit potential from asset sales. Alternatively, the complexities of the ERC market could have a negative effect.

\section{Conclusions}

The rapid aging of fossil-fired power plants represents a significant economic opportunity. The residual value of these plants is large. We have reviewed a number of mechanisms through which the use of this resource might function. There is no clear pattern which would indicate the best mechanism. The approaches which might increase the use of these facilities involve transferring these assets to private producers. These approaches will require regulatory policies that make asset transfers attractive to all parties.

Incentive ratemaking could give utilities an opportunity to earn higher profits for their stockholders by selling off assets that they were not intending to use any time soon. Without the financial op portunity to profit from a sale, a utility is likely to hold onto an old power production site. The few cases where sales have occurred appear to have been motivated primarily by financial distress. The one successful case involving a lease was motivated by both time and financial constraints. Profit sharing rules are becoming increasingly common in the electric utility industry in areas of power marketing. Such policies might usefully be extended to asset markets.

By adopting a consistent and sophisticated treatment of asset dispositions, regulators can use incentive ratemaking mechanisms to craft an efficient, competitive re-powering market. With some benefit in the arrangement for the stockholders, a utility is more likely to entertain the option of selling off an old plant if an IPP has introduced an attractive bid for re-powering. Careful integration of these incentive policies with competitive bidding programs could lead to more efficient utilization of the nation's electric generating resources than under conventional practices. 


\section{Acknowledgements}

This work was supported by the Deputy Assistant Secretary for Coal Technology under Contract No. DE-AC03-76SF00098. We would like to thank Jack Siegel, Tom Grahame and Jerry Temchin for their review and support. We also acknowledge assistance from Steve Jenkins, Destec Energy; L.Keller, Methacoal Corporation; Steve Litkovitz, Massachusetts Department of Public Utilities; Roger Naill, Applied Energy Services; Joseph Plummer, Duquesne Light Company; Bernard Strait, Nordic Power; Charles Walker, Nevada Public Service Commission; and Robin Warsinke, Nevada Power.

\section{References}

Bechtel Group Inc., "Major Options and Considerations for Re-powering with Gas Turbines," EPRI GS-6156, 1989.

Benning, J., Testimony on behalf of Public Service Company of Indiana, Indiana Utility Regulatory Commission Cause No. 37414-S2, 1989.

Brown, L., M.Einhorn and I.Vogelsang, "Incentive Regulation: A Research Report, Federal Energy Regulatory Commission 89-3," 1989.

Bruce, S., "Reshuffling the Resource Deck at Entergy," The Electricity Journal, v. 3, no. 4, May, 1990.

California Public Utilities Commission (CPUC), Decision No. 82-12-121, 1982.

Clayton, D.J., Testimony on behalf of Duquesne Light Company in Pennsylvania Public Utility Conımission Docket No.P-900485, 1990.

Duquesne Light Company, White Paper, December 3, 1990.

Electric Power Research Institute, "TAG-Technical Assessment Guide, V.1: Electricity Supply,” EPRI P-4463-SR, 1986.

Farber, M., "Economic Evaluation Of Plant-upgrading Investments, v.2: Case Studies," EPRI EA-3890, 1985.

Florida Power and Light Company, "Petition to Determine Need for Electrical Power Plant 1993-1996," 1989a.

Florida Power and Light Company, "Request for Power Supply Proposals-1989 Solicitation," $1989 \mathrm{~b}$. 
Florida Power and Light Company, “1989 Solicitation Supplemental Information,” 1990.

Hausker, Karl, "Coping with the Cap: How Auctions can Help the Allowance Market Work," Public Utilities Fortnightly, v. 125, p. 28-34, May 24, 1990.

Hoppe, J., Illinois Commerce Commission, private conversation, 1990.

Jones, T.D., Testimony on behalf of Duquesne Light Company in Pennsylvania Public Utility Commission Docket No.P-900485, 1990.

Joskow, P. and R. Schmalensee, "Incentive Regulation for Electric Utilities," Yale Journal of Regulation v.4, 1-49, 1986.

Keller, L., Methacoal Corporation, private conversation, 1990.

Litkovitz, S., Massachusetts Department of Public Utilities, private conversation, 1991.

Massachusetts Department of Public Utilities (MDPU), Docket No. 86-36-E, 1988.

Naill, R., Applied Energy Services, private conversation, 1990.

Nevada Public Service Commission (NPSC), Opinion and Interim Order in Docket No. 90390, 1990a.

Nevada Public Service Commission (NPSC), Final Order in Docket No. 90-390, 1990 b.

New York Public Service Commission (NYPSC), Opinion No. 85-13, 1985.

New York Public Service Commission (NYPSC), Opinion No. 83-17, Case 27741, 1983.

Niagara Mohawk Power Corporation (NMPC), "Competitive Bidding Guidelines and Request for Proposals No.1," November, 1989a.

Niagara Mohawk Power Corporation (NMPC), "Transcript of the general question and answer session of the Pre-Bid Meeting," December 15, $1989 \mathrm{~b}$.

Power and Energy Briefs, "WEPCO Plant Must Meet PSD Rules,” v.23, October, 1990.

Rodgers, J., "PSI's Market-Based Bulk Power and Transmission Proposal," The Electricity Journal, v.3, no.2, March, 1990.

Shirmohammadi, D. and C.Thomas, "Valuation of the Transmission Impact in a Resource Bidding Process," IEEE Transactions on Power Systems, 1990 (to appear). 
Steinberg, M., Wisconsin Electric Power Company, private conversation, 1991.

Strait, B., Nordic Power, private conversation, 1990.

U.S. Congress Office of Technology Assessment (USOTA), "Electric Power Wheeling and Dealing: Technological Considerations for Increasing Competition," OTA-E409, Washington, DC, U.S. Government Printing Office, p 163, May 1989.

U.S. Court of Appeals, 7th Circuit, Case No. 88-3264 and 89-1339, January, 1990.

U.S.Department of Energy, "The Role of Re-powering in America's Power Generation Future," DOE/FE-0096, 1987.

Wellford, W.H. and H. Robertson, "Bidding for Power: The Emergence of Competitive Bidding in Electric Generation," National Independent Energy Producers, 1990.

Wolfe, T., Massachusetts Department of Public Utilities, private conversation, 1990. 

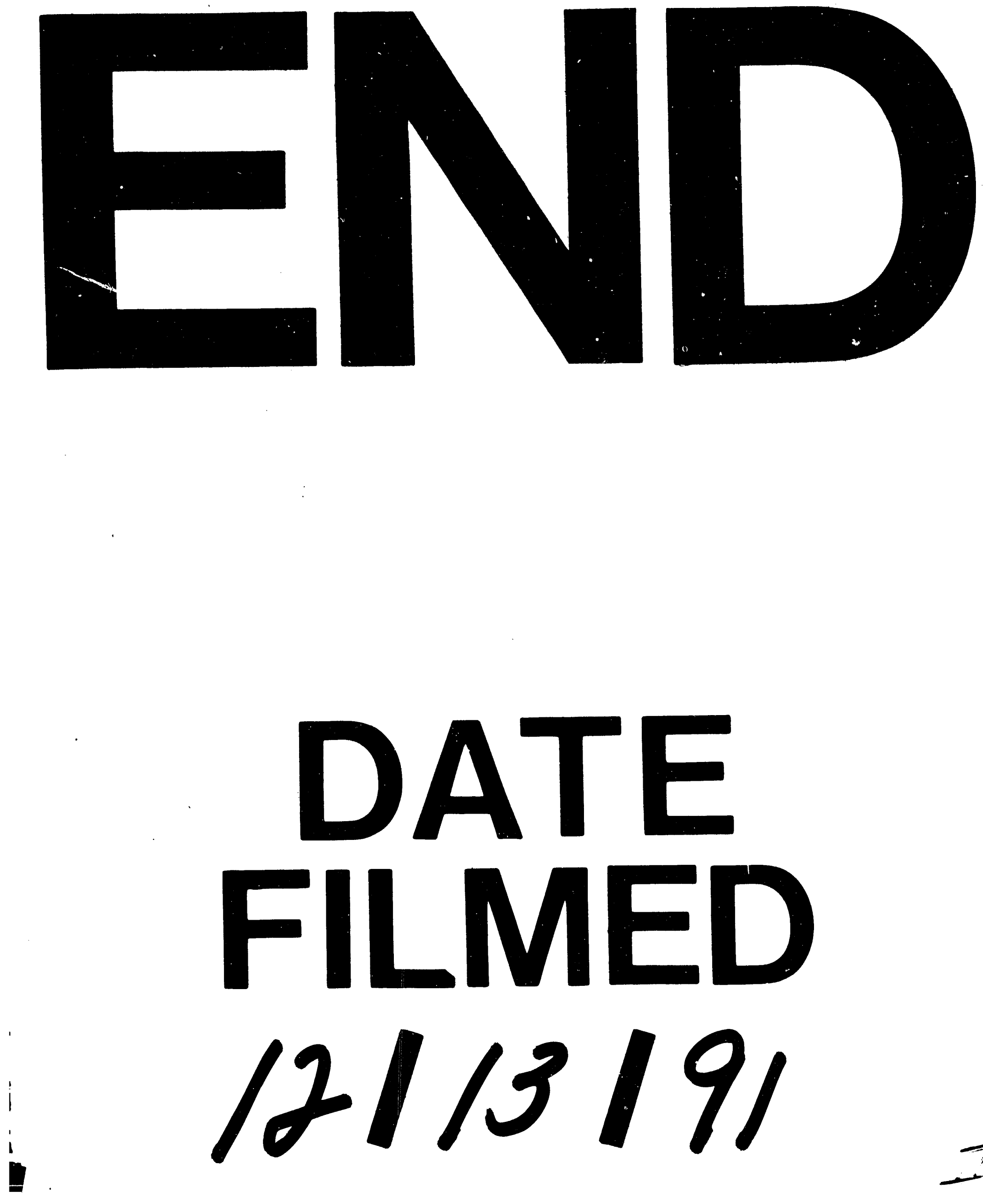
